\title{
The genus Inversispina Zhang, in Zhang, Wang et Zhang, 1997, new to the millipede fauna of Taiwan, with the description of a new species (Diplopoda: Polydesmida: Paradoxosomatidae: Alogolykinae)
}

\section{РоА Inversispina Zhang, in Zhang, Wang et Zhang, 1997, новый Аля Аиплопод фауны Тайваня, с описанием нового вида (Diplopoda: Polydesmida: Paradoxosomatidae: Alogolykinae)}

\section{Chao-Chun Chen ${ }^{1}$, Sergei I. Golovatch ${ }^{2}$ \& Hsueh-Wen Chang ${ }^{1,3}$ Ч.Ч. Чень ${ }^{1}$, С.И. Головач², С.В. Чан ${ }^{1,3}$}

\footnotetext{
${ }^{1}$ Department of Biological Sciences, National Sun Yat-Sen University, 70 Lien-Hai Rd., Kaohsiung, Taiwan 804 ROC.

${ }^{2}$ Институт проблем экологии и эвлюции РАН, Ленинский проспект, 33, Москва 119071 Россия.

${ }^{2}$ Institute for Problems of Ecology and Evolution, Russian Academy of Sciences, Leninsky pr. 33, Moscow 119071, Russia.

${ }^{3}$ Corresponding author
}

KEY WORDS: Diplopoda, Paradoxosomatidae, Alogolykinae, taxonomy, new species, Taiwan.

КЛЮЧЕВЫЕ СЛОВА: Diplopoda, Paradoxosomatidae, Alogolykinae, таксономия, новый вид, Тайвань.

ABSTRACT. Inversispina taiwanensis sp.n. is being described from northern Taiwan. This is the second species of Inversispina Zhang, in Zhang, Wang et Zhang, 1997, its type species, I. tortiapicalis Zhang, in Zhang, Wang et Zhang, 1997, being known from central continental China. This new species is also the first representative of the South to Southeast Asian subfamily Alogolykinae in Taiwan.

РЕЗЮМЕ. Из Северного Тайваня описан новый вид Inversispina taiwanensis sp.n. Это второй вид в составе рода Inversispina Zhang, in Zhang, Wang et Zhang, 1997, в котором типовой вид I. tortiapicalis Zhang, in Zhang, Wang et Zhang, 1997, известен из центральной части материкового Китая. Этот новый вид - одновременно и первый представитель южно- и юго-восточно-азиатского подсемейства Alogoly-kinae на Тайване.

\section{Introduction}

The millipede fauna of Taiwan, like that of numerous tropical countries, is predominated by species of the order Polydesmida which, in turn, is dominated by the family Paradoxosomatidae [Korsós, 2004]. At the moment, this large family is known to be represented in Taiwan by 22 species from 12 genera [Korsós, 2004, Chen et al., 2006a, b, 2008, 2010a, b, 2011], all of them belonging in the largest subfamily Paradoxosomatinae.

All the more interesting is the discovery in Taiwan of the first species of the small South to Southeast Asian subfamily Alogolykinae. This is a new species which belongs to the hitherto monobasic genus Inversispina Zhang, in Zhang, Wang et Zhang, 1997, in which the type, and only, species, I. tortiapicalis Zhang, in Zhang, Wang et Zhang, 1997, is known from a south-temperate woodland at $1100 \mathrm{~m}$ elevation in the Wuling Mountains, southern Hubei Province, central China $\left(29.8^{\circ} \mathrm{N}, 110.0^{\circ} \mathrm{E}\right)$.

The holotype of the new Taiwanese species is housed in the collection of the National Museum of Natural Science, Taichung, Taiwan (NMNS), whereas the paratype in the National Sun Yat-Sen University, Kaohsiung, Taiwan (NSYSU).

\section{Descriptive part}

Inversispina taiwanensis sp.n.

Figs 1-18.

MATERIAL. Holotype $\sigma^{7}$ (NMNS-6676-001), Taiwan, Yilan County, Yuanshan Township, $24^{\circ} 47^{\prime} 23^{\prime}$ N, 121 $1^{\circ} 39^{\prime} 47^{\prime \prime} \mathrm{E}$ (or $\left.24.79^{\circ} \mathrm{N}, 121.66^{\circ} \mathrm{E}\right), 220 \mathrm{~m}$ a.s.1., 4 February 2007 , leg. M.H. Hsu. Paratype $\sigma^{T}$ (NSYSU), New Taipei City, Wulai District (formerly, Taipei County, Wulai Township), Wulai, forest, ca $1000 \mathrm{~m}$ a.s.1., March 2002, C.C. Chen and C.E. Iang.

NAME. To emphasize the provenance of the new species from Taiwan.

DIAGNOSIS. Differs from I. tortiapicalis Zhang, in Zhang, Wang et Zhang, 1997, the only hitherto known congener, in being somewhat smaller (14-16 versus $18-20 \mathrm{~mm}$ in length, $1.4-1.5$ versus $2.0 \mathrm{~mm}$ in width), showing no adenostyles (versus dentigerous adenostyles observed on male femora 1-9), the paraterga not extending behind the rear tergal margin even on seg- 

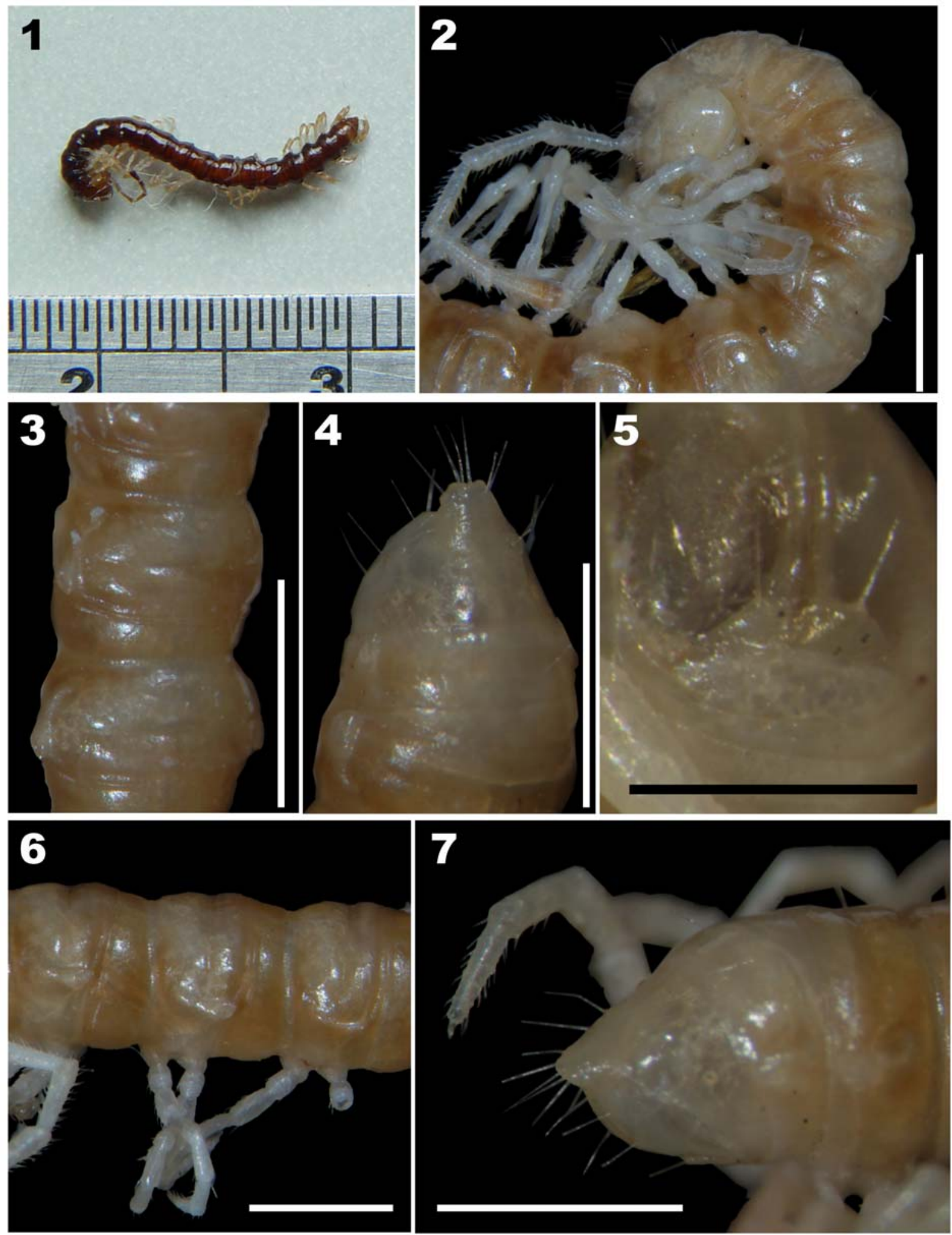

Figs 1-7. Inversispina taiwanensis sp.n., holotype: 1 - habitus, dorsal view; 2 - anterior body portion, lateral view; 3 - segments 9 and 10, dorsal view; $4 \& 7$ - telson, dorsal and dorsolateral views, respectively; 5 - hypoproct, ventral view; 6 - segments 9-11, lateral view. Scale bars: $1.0(2-4,6 \& 7)$ and $0.5 \mathrm{~mm}(5)$.

Рис. 1-7. Inversispina taiwanensis sp.n., голотип: 1 - габитус, сверху; 2 - передняя часть тела, сбоку; 3 - сегменты 9 и 10 , сверху; 4 и 7 - тельсон, соответственно сверху и одновременно сверху и сбоку; 5 - гипопрокт, снизу; 6 - сегменты 9-11, сбоку. Масштаб: 1,0 (2-4, 6 и 7) и 0,5 мм (5). 

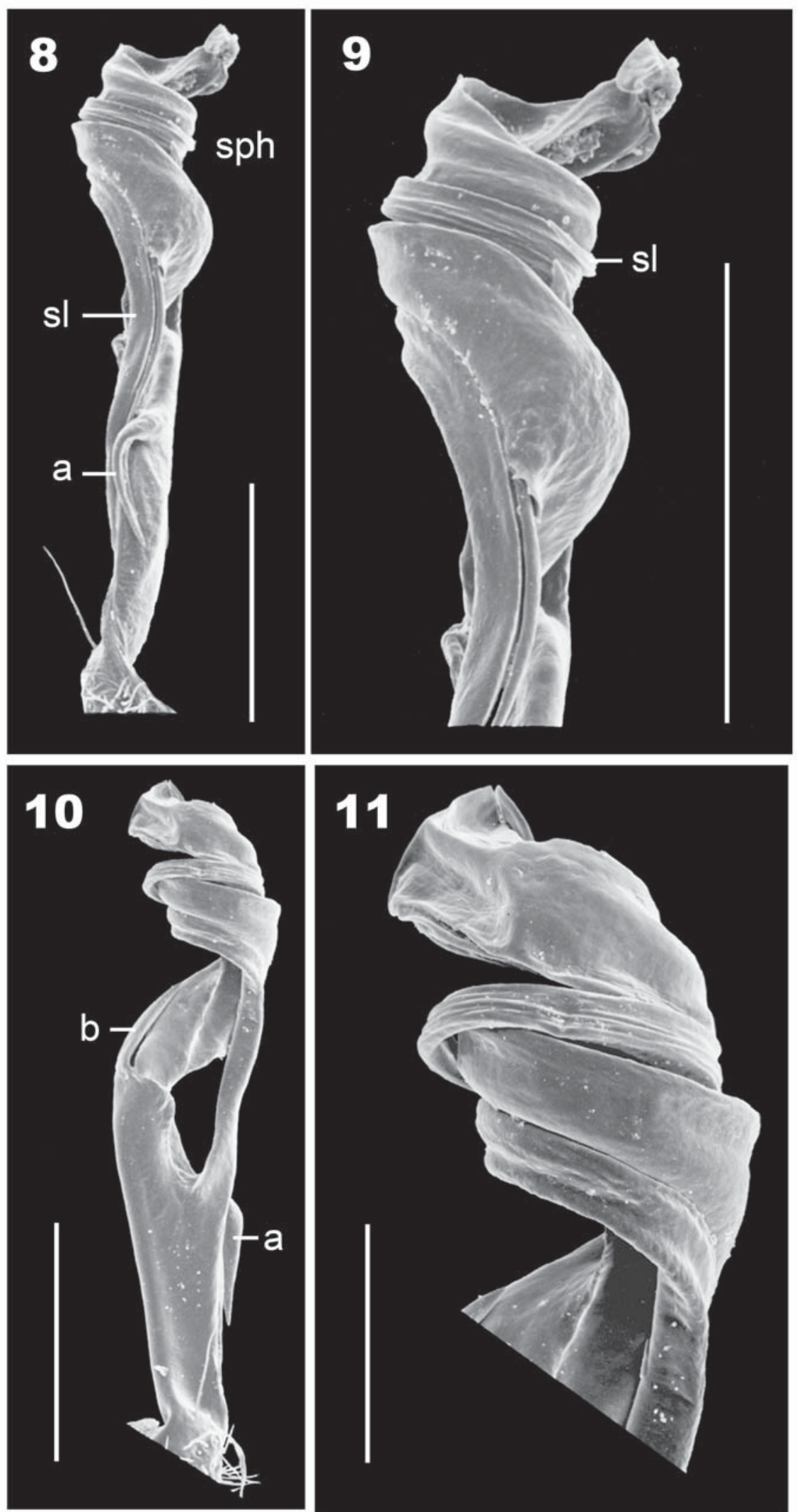

Figs 8-11. Inversispina taiwanensis sp.n., right gonopod of holotype, mesal, mesal, ventral and ventral views, respectively. Scale bars: $0.5(8-10)$ and $0.2 \mathrm{~mm}(11)$.

Рис. 8-11. Inversispina taiwanensis sp.n., правый гонопод голотипа, соответственно изнутри, изнутри, снизу и снизу. Масштаб: $0,5(8-10)$ и 0,2 мм (11). 

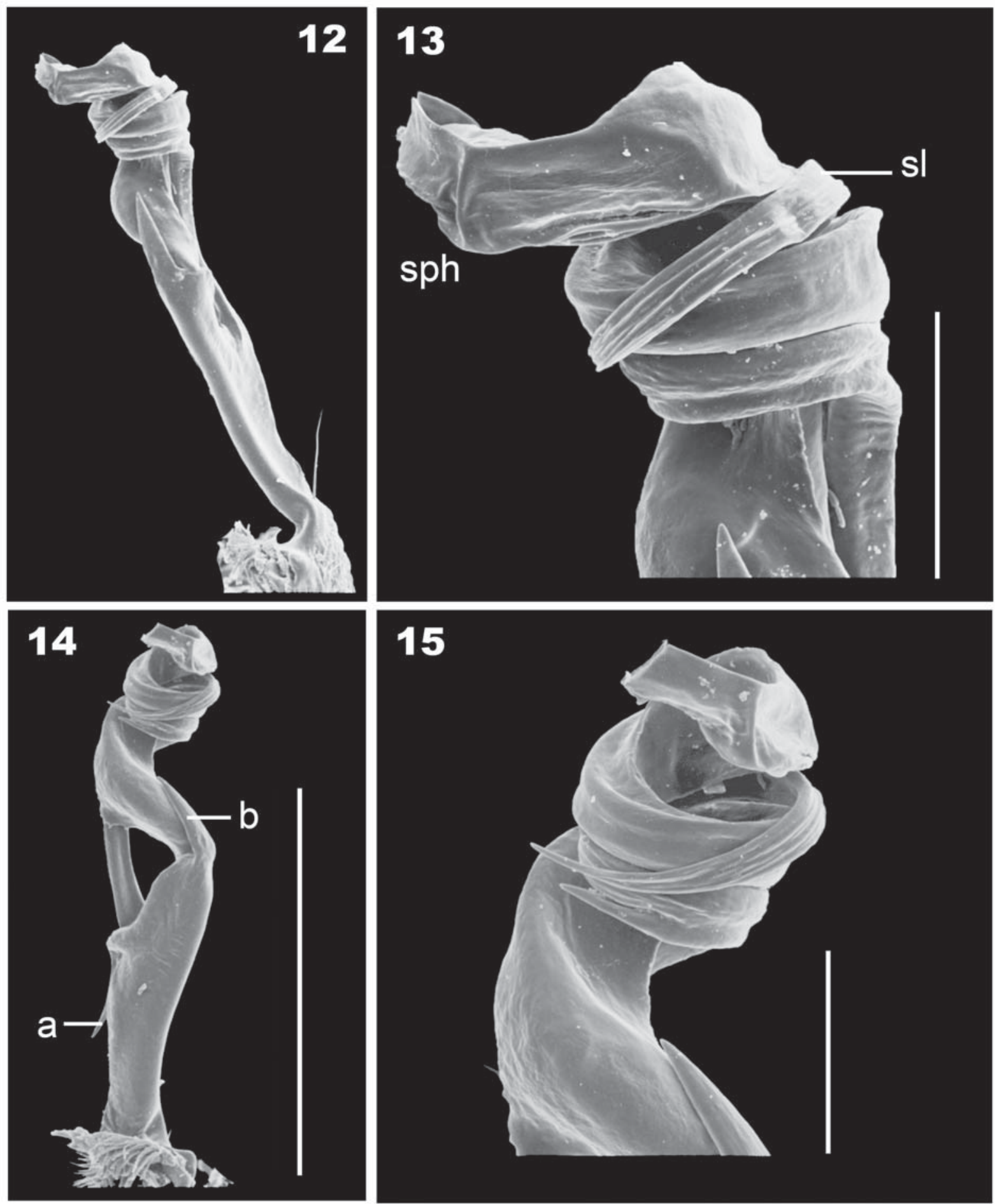

Figs 12-15. Inversispina taiwanensis sp.n., right gonopod of holotype, lateral, lateral, dorsal and dorsal views, respectively. Scale bars: $1.0(12 \& 14)$ and $0.2 \mathrm{~mm}(13 \& 15)$.

Рис. 12-15. Inversispina taiwanensis sp.n., правый гонопод голотипа, соответственно сбоку, сбоку, сверху и сверху. Масштаб: $1,0$ (12 и 14$)$ и 0,2 мм (13 и 15$)$.

ment 19 , a different pattern of tergal setation $(3+3$ versus $4+4$ behind the front margin of the collum, and $1+1$ versus $2+2$ in the front/presulcus part of the fol- lowing metaterga), as well as a slightly shorter spine a and, especially, a far more strongly coiled solenophore of the gonopod. 


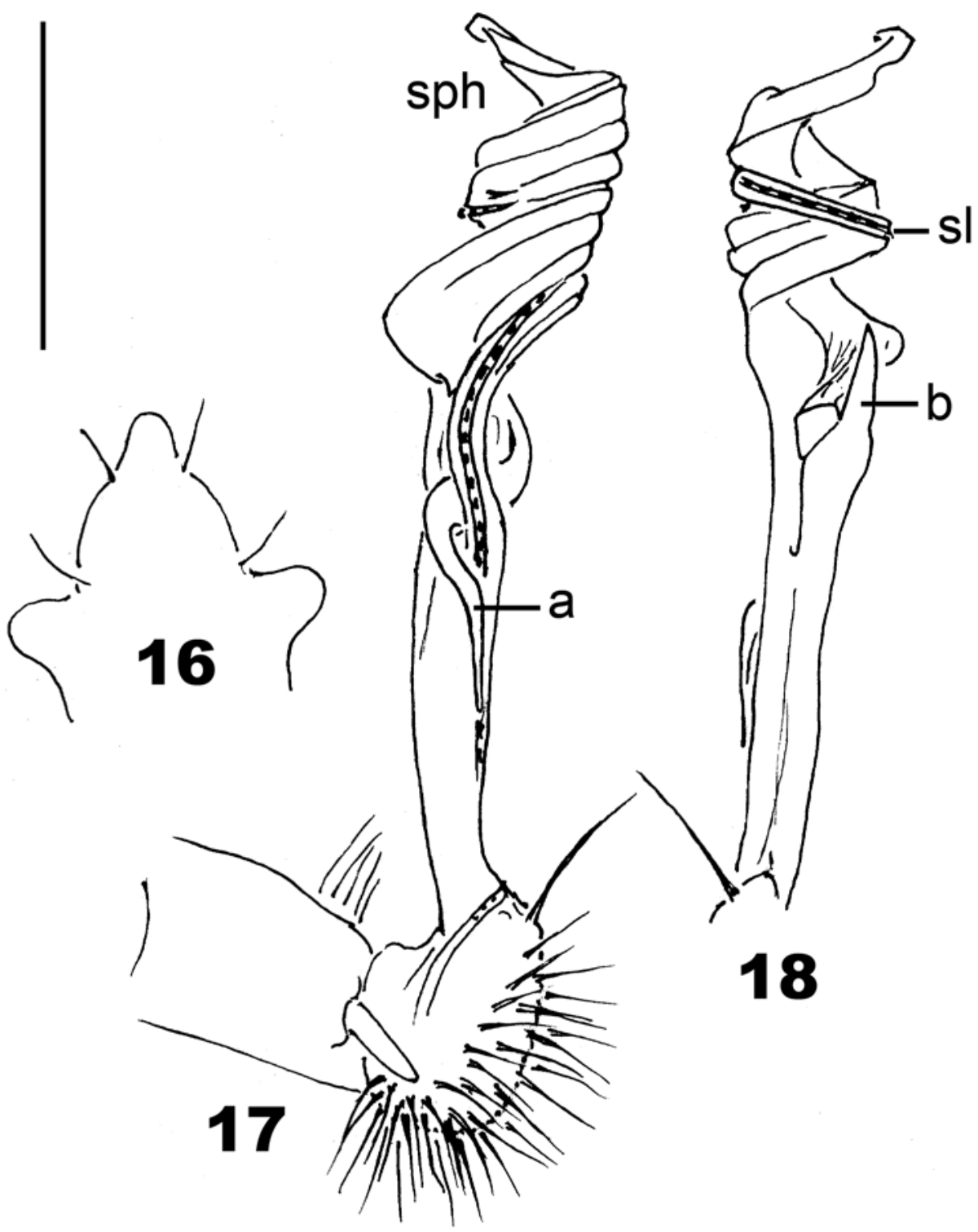

Figs 16-18. Inversispina taiwanensis sp.n., holotype: 16 - sternal lobe between coxae 4, ventral view; 17 \& 18 - left gonopod, mesal and subventral views, respectively. Scale bar: $0.5 \mathrm{~mm}$.

Рис. 16-18. Inversispina taiwanensis sp.n., голотип: 16 - стернальная пластина между коксами 4, снизу; 17 и 18 - левый гонопод, соответственно изнутри и сбоку. Масштаб: 0,5 мм.

DESCRIPTION. Length of holotype ca $14 \mathrm{~mm}$, width of midbody pro- and metazona ca 1.0 and $1.4 \mathrm{~mm}$, respectively. Length of paratype ca $16 \mathrm{~mm}$, width of midbody pro- and metazona ca 1.1 and $1.5 \mathrm{~mm}$, respectively.

Coloration in alcohol uniformly very light brown to light brown; distal half of antennomere 6 and entire antennomere 7 slightly infuscate, light brown; venter, legs, remaining antennomeres and telson pallid, telopodites of walking legs sometimes light yellow (Figs $2-7)$. Coloration strongly faded upon long-term preservation, freshly fixed holotype having been uniformly dark brown (Fig. 1).

Head with transverse $2+2$ setae on sides of epicranial groove, clypeus and interantennal isthmus moder- ately setose. Body subcylindrical, postcollum constriction faint; in width, collum $<$ head $\leq$ segment $2<3<4$ $<$ segments $5-17$, thereafter body gradually and gently tapering both in width and height towards telson. Antennae long and slender, reaching posterior edge of metatergum 3 dorsally (Fig. 2).

Surface generally shining and smooth, sparsely and finely microgranulate only below paraterga. Paraterga (Figs 2, 3 and 6) poorly developed, gradually growing subspiniform caudally, reaching rear edge on metaterga $2-19$, but never surpassing it; lying at ca $1 / 2$ body height; with two small dentiform projections on calluses, these being thinner on poreless segments, broader on pore-bearing ones; calluses (Figs $3 \& 6$ ) always 
delimited by a sulcus dorsally, but a ventral sulcus mostly observed in caudal half only on pore-bearing segments. Axial line thin, visible only on postsulcus halves of metaterga 5-17. Limbus thin, caudal margin entire. Segments slightly constricted, stricture (Figs 3 \& 6) dividing pro- and metazona shallow, wide, roughly beaded at bottom dorsally down to pleural region, increasingly shallow and smooth ventrad. Tergal setae retained on collum and segments $2-19,3+3$ at anterior edge of collum, $1+1$ placed just before transverse sulcus on metaterga 2-19, a seta on each lateral callus on collum and paraterga 2 and 3. Ozopores (Figs 2, 3 \& 6) lateral, lying on callus at ca $1 / 3$ metatergal length off caudal edge (Figs 2, 3 \& 6). Transverse sulcus (Figs 3 $\&$ 6) well-developed on segments 5-18, only poorly traceable on segments $2-4$ and 18 , missing on segment 19; narrow, shallow, neither beaded at bottom nor reaching bases of paraterga. Pleurosternal carinae (Fig. 2) present as narrow ridges only on segments 2 and 3, thereafter missing. Epiproct (Figs 4 \& 7) short, coniform, flattened dorsoventrally; tip slightly concave; pre-apical papillae (Figs $4 \& 7$ ) small, placed close to apex. Hypoproct (Fig. 5) subtrapeziform, caudal margin almost straight, 1+1 setae at caudal corners situated on well-separated knobs, sides almost straight.

Sterna sparsely setose, each cross-impression with both transverse sulcus and axial groove poorly-developed; an unusually large, long, subtriangular, poorly setose lamina between coxae 4 (Fig. 16). Legs long and slender, mostly about twice as long as midbody height, adenostyles missing; legs 1-10 (except for gonopods) with tarsal brushes.

Gonopods (Figs 8-15, 17 \& 18) highly complex. Coxite elongate, rather short, subcylindrical, setose distodorsally; cannula usual. Telopodite slender, strongly elongated, ca 4 times as long as coxite. Prefemoral part short and stout, almost twice shorter than femorite, as usual densely setose. Femorite nearly as long as acropodite, very long, broadened distally, supporting seminal groove running entirely on medial side (not twisted), delimited by an oblique sulcus distomedially; distalmost part with a long, retrorse, mesal spine (a) beginning distally of a very long, ribbon-shaped solenomere (sl), as well as with an evident, erect, apicolateral spine (b). Solenophore (sph) strongly coiled, set off from femorite by a sulcus, forming about three spirals, lamellate, mostly represented by a lamina lateralis, supporting sl all along.

\section{Conclusions}

Among the basic traits distinguishing the South to Southeast Asian subfamily Alogolykinae (as well as the Australian Australosomatinae) is the presence in most of its constituent species and genera of adenostyles on $\sigma^{7}$ femora 1. Inversispina appears to show remarkable variation in this character, since only $I$. tortiapicalis has adenostyles on $\sigma^{7}$ femora 1 (as well as on several following ones), whereas I. taiwanensis sp.n. is totally devoid of these structures. Apparently, the utility of adenostyles in the higher classification of Paradoxosomatidae has been exaggerated, since it turns out to be only species-characteristic at least within Alogolykinae.

A new, amended diagnosis of the genus would read as follows.

Inversispina Zhang, in Zhang, Wang et Zhang, 1997

Inversispina Zhang, in Zhang, Wang et Zhang, 1997: 517.

DIAGNOSIS. Alogolykinae with 20 body segments. Paraterga and pleurosternal carinae poorly-developed. Sternal lamina between $\sigma^{r}$ coxae 4 unusually prominent. Tarsal brushes present. Adenostyles on some $\sigma^{7}$ femora either present or absent.

Gonopods highly complex. Coxite rather short, subcylindrical, setose distodorsally. Prefemoral part short, about twice as short as femorite. Femorite long, nearly or fully as long as acropodite, without traces of torsion, distally carrying a retrorse and an erect dentiform spine, with a long, ribbon-shaped solenomere starting at base of both. Solenophore strongly coiled, set off from femorite by a transverse sulcus, lamellate, mostly represented by a lamina lateralis, supporting solenomere all along.

Type species: Inversispina tortiapicalis Zhang, in Zhang, Wang et Zhang, 1997; by original designation.

Other species included: Inversispina taiwanensis sp.n.

DISTRIBUTION. Central mainland China [Zhang et al., 1997] and Taiwan. Inversispina taiwanensis sp.n. has been encountered in low- to midmontane woodlands in the northern and northeastern parts of the island, likely representing a local endemic species.

ACKNOWLEDGEMENTS. We are most grateful to the National Science Council, Taiwan, Republic of China and to the Russian Academy of Sciences, Moscow, Russian Federation for the support rendered to the Taiwanese and Russian teams, headed by H.W. Chang and S.I. Golovatch, respectively, to actively collaborate in our joint ecofaunistic studies on the Myriapoda of Taiwan in 2009-2011.

\section{References}

Chen C.C., Golovatch S.I., Chang H.W. 2006a. The millipede tribe Nedyopodini, with special reference to the fauna of Taiwan (Diplopoda: Polydesmida: Paradoxosomatidae) // Journal of Natural History. Vol.39. No.47. P.3997-4030.

Chen C.C., Golovatch S.I., Chang H.W. 2006b. The millipede tribe Sulciferini in Taiwan (Diplopoda: Polydesmida: Paradoxosomatidae) // Norwegian Journal of Entomology. Vol.53. P.249270 .

Chen C.C., Golovatch S.I., Chang H.W. 2008. Identity of the east Asian millipede Habrodesmus inexpectatus Attems, 1944 (Diplopoda: Polydesmida: Paradoxosomatidae) // Journal of Natural History. Vol.42. Nos 39/40. P.2547-2556.

Chen C.C., Golovatch S.I., Mikhaljova E.V., Chang H.W. 2010a. The millipede genus Anoplodesmus Pocock, 1895, recorded in Taiwan for the first time, with descriptions of two new species (Diplopoda: Polydesmida: Paradoxosomatidae: Sulciferini) // Zootaxa. No.2399. P.20-30. 
Chen C.C., Golovatch S.I., Chang H.W. 2010b. Revision of the endemic Taiwanese millipede genus Aponedyopus Verhoeff, 1939, with descriptions of two new species (Diplopoda, Polydesmida, Paradoxosomatidae) // ZooKeys. No.72. P. $1-21$.

Chen C.C., Golovatch S.I., Chang H.W., Chen S.H. 2011. Revision of the Taiwanese millipede genus Chamberlinius Wang, 1956, with descriptions of two new species and a reclassification of the tribe Chamberlinini (Diplopoda, Polydesmida, Paradoxosomatidae, Paradoxosomatinae) // ZooKeys. No.98. P.1-27.
Korsós Z. 2004. Checklist and bibliography of millipedes (Diplopoda) of Taiwan // Collection and Research. Vol.17. P.11-32.

Zhang C.Z., Wang D.Q., Zhang F.X. 1997. [Two new genera and four new species of Diplopoda from Wuling Mountains area] // Song D.X. (ed.). Invertebrates of Wuling Mountains area, Southwestern China. Science Press, Beijing. P.508-522 [In Chinese, with English summary].

Responsible editor K.G. Mikhailov 